\title{
Optimal Sizing of Hybrid Renewable Energy System for Off-Grid Electrification: A Case Study of University of Ibadan Abdusalam Abubakar Post Graduate Hall of Residence
}

\author{
Ifedayo Mofolorunso Opedare*, Taiwo Matthew Adekoya**‡, Adedayo Emmanuel Longe*** \\ "Centre for Petroleum, Energy Economics and Law (CPEEL), University of Ibadan, Nigeria. \\ ${ }^{* *}$ Centre for Petroleum, Energy Economics and Law (CPEEL), University of Ibadan, Nigeria. \\ ${ }^{* * *}$ Centre for Petroleum, Energy Economics and Law (CPEEL), University of Ibadan, Nigeria. \\ (ifedayoopedare@yahoo.com, adekoyatm@gmail.com,longeemmanuel28@gmail.com) \\ $\$$ Corresponding Author; Taiwo Matthew Adekoya, \\ adekoyatm@gmail.com
}

Received: 26.11.2020 Accepted:20.12.2020

\begin{abstract}
The main objective of this study is to design a Hybrid Renewable Energy System (HRES) to meet the energy demand of a major Post Graduate Student residential hostel. The specific objectives are to estimate the energy demand, perform economic and technical analysis of various combination of renewable energy technologies that can meet the estimated energy demand and to select the appropriate and optimum hybrid system for the hall of residence. Quantitative analysis was used to determine the energy demand of the hall of residence while the solar resource information was obtained from the NASA Surface Meteorology. The Hybrid Optimization Model for Electric Renewables (HOMER) software was used for analysis. The components of the system considered were solar photovoltaic (PV), diesel generator, batteries and inverter. The optimised hybrid system obtained was also compared to a system in which a diesel generator serves as the sole source of electricity supply. Economic analysis using the total net present cost and levelized cost of enegy was employed to determine the optimized hybrid combination. Environmental considerations were also made based on the amount of Carbon dioxide emitted per year. Results indicates that electricity generation through a hybrid system made up of $1000 \mathrm{~kW} \mathrm{PV}, 110 \mathrm{kVA}$ generator, $11791 \mathrm{kWh}$ Surrette S6CS25P battery arranged in parallel strings and a $220 \mathrm{~kW}$ Inverter had the lowest total net present cost, lowest cost of energy with a low emission. Hence, Hybrid Renewable Energy Systems (HRES) should be employed in the production of electricity due to its ability to reduce environmental degradation while ensuring a low total net present cost and a low cost of energy.
\end{abstract}

Keywords: Hybrid renewable energy system, renewable energy, HOMER, off-grid electrification.

\section{Introduction}

The various sources of energy can be grouped into two, namely non-renewable energy sources and renewable energy sources [1]. A non-renewable energy source comes from a finite stock while a renewable energy source can be replaced/replenished naturally [2]. Four major sources of nonrenewable energy are crude oil, natural gas, coal and uranium
[3]. The major source of renewable energy is solar energy [4]. Biomass, wind and hydropower which are other sources of renewable energy are secondary sources of solar energy biomass products can be linked to the process of photosynthesis, wind results from heating of the planet by the sun, and the sun drives the evapotranspiration cycle which allows generation of power by water [5]. Other non-solar 
renewable energy sources are geothermal energy and tidal energy.

The availability of renewable energy is intermittent in nature; hence it needs to be complemented [6]. As a result, a hybrid system consisting of two or more energy sources are usually designed [7]. This kind of system helps to complement the drawbacks of individual sources of energy [8] and it is stable, reliable and efficient [9], eco-friendly and profitable for remote locations [10]. The design goals of an hybrid system have been highlighted to be minimal cost of producing power; reduced emision; reduced total cycle life cost; increased reliability; and if connected to the grid, minimal purchase of power from the grid [6].

One of the world's most critical development challenge is addressing the lack of access, by billions of people, to reliable and affordable energy services. Improving access to affordable and sustainable energy services is prominent and absolutely central to the broader developmental efforts aimed to reduce poverty, improve education, health, gender equality and environmental sustainability [11].

In Nigeria, one of the problems facing the power sector is its inability to easily diversify electricity generation. Although the country is blessed with many energy sources such as solar, biomass, nuclear, gas, crude oil, hydro, biofuel among others, the problem has been which is the most efficient and least costly to adopt. Efforts to generate electricity have been linked to the use of associated gas through various Independent Power Plants (IPP) projects. Such projects include Kaduna power plant, Azura power station (IPP), Calabar Power Station (IPP), Egbema Power Station (NIPP), Ihovbor Power Station (NIPP), Omoku II Power Station (NIPP), Omotosho II Power Station (NIPP), Olorunsogo II Power Station (NIPP), Alaoji Power Station (NIPP), Sapele Power Station, Geregu II Power Station (NIPP), Aba Power Station (IPP), Rivers IPP, Trans-Amadi Power Station (IPP), Omoku Power Station (IPP), AES barge (IPP), Ibom Power Station (IPP), Afam VI Power Station (IPP), Kwale Okpai Power Station (IPP), Papalanto (Olorunsogo) Power Station, Omotosho I Power Station, Geregu I Power Station, Afam I-IV, \& V power station, Transcorp-Ughelli Power Station, Egbin Thermal Power Station [12]. Despite the installed capacity of these stations, the Nigerian power sector is still deficient in terms of meeting the increasing demand for power. As a result, various firms, homes and industries have resorted to generate power independently through the use of generators. These generators use only fossil fuels which have negative effects on the environment and have high operational and maintenance costs. Hence, the need to study other systems of generating power independently. The use of hybrid renewable energy system for independent power generation is considered in this paper.

The main objective of this study is to design a Hybrid Renewable Energy System (HRES) to meet the energy demand of a major Post Graduate Student residential hostel in the University of Ibadan which is Nigeria's premier university. The energy demand of the Post-Graduate Hall of Residence will be estimated. Then an economic and technical analysis of meeting the energy demand from three scenarios (solar only, diesel only and a hybris of solar and diesel) are considered. From the techno-economic analysis carried out, the appropriate and optimum hybrid system would be selected.

This study is organized in five sections. This first section has introduced the study. The second section is the literature review. Section three discusses the methodology used while results are discussed in the fourth section. The last section gives a conclusion.

\section{Literature Review}

Various sources of hybrid renewable systems have been proposed. Wind-PV hybrid system with a battery [13], windPV hybrid system in a micro grid [14], wind-pumped hydro storage backed up by a generator [15], PV-hydro-wind hybrid system [16], battery supported PV-wind-hydro hybrid [17] and PV-wind-diesel hybrid system [18] have been proposed and investigated.

Analysis have also been done for different locations. Three scenarios (diesel only, diesel/PV and diesel/PV/battery) were considered for supplying electricity to a remote area in Cambodia [19]. PV/Wind/battery system [20] and $\mathrm{PV} / \mathrm{Wind} /$ diesel [21] have been designed for different areas in Pakistan while PV/diesel/batttery system was designed for a village in Eastern Nigeria [22]. A hybrid power system was modelled and designed for a house in Benin City, Nigeria [23] while a wind/diesel/battery hybrid system was discovered to be the most economical combination for residential electric power supply in Iran [24]. A technical and financial analysis for sustainably generating electricty from solar, biomass and wind for 10 houses in Morocco has been performed [25] while a hybrid renewable power system has been designed for sustainable electricity in Benin, Nigeria [26].

Furthermore, some works have considered on-grid and off-grid power analysis. For example, the economic feasibility of a grid connected hybrid power system [27] and feasibility study of an off-grid hybrid system [28] have been done. A techno-economic analysis for a hybrid power system for off grid communities [29] and an off grid residence has been done [30]. Also, a grid connected hybrid system composed of wind, solar and hydrogen has been performed [31]. In addition, a grid integrated inverter to improve power quality of a HRES has also been designed and modelled [32].

In brief, different works have focused on different objectives. Some works focused only on designing a hybrid system to generate a certain amount of power, some were focused on comparison between different hybrid systems, some focused on designing different hybrid systems to deliver a specific amount of power while others focused on making optimal choice between different hybrid configurations.

Adding to the body of knowledge for off-grid power generation, this paper aims to design a hybrid off-grid power system for a post graduate hall of residence in the University of Ibadan, Ibadan, Oyo State, Nigeria.

\section{Methodology}

\subsection{Study Area and Data Collection}

The hall of residence surveyed in this study is Abdusalam Abubakar Post-Graduate Hall, University of Ibadan (UI) which is located at latitude of $7.444306^{\circ} \mathrm{N}\left(7^{\circ} 26^{\prime} 39.5^{\prime \prime} \mathrm{N}\right)$ and 
longitude of $3.8995^{\circ} \mathrm{E}\left(3^{\circ} 53^{\prime} 58.2^{\prime \prime} \mathrm{E}\right)$. The hall of residence's primary source of power supply is the Ibadan Electricity Distribution Company IBEDC.

Data was collected from the hall under study through onsite analysis and oral interviews of students residing in the hall, workers and the management staffs.

\subsection{The Hybrid System}

The proposed hybrid energy system would be made up of solar PV and a diesel generator. The primary source of electricity would be the solar PV with an inverter backed up by batteries. The diesel generator would be used as backup and in emergency situations. The main components for the system are PV panels, batteries, diesel generator and an inverter. The photovoltaic (PV) panels convert electromagnetic radiation from the sun into direct current (DC). The direct current produced by the PV panels is converted to alternating current (AC) by the inverter. The batteries would store excess electricity produced. The diesel generator is important in case of extra load or when there is a black-out and the battery bank is not sufficient to carry the load extra load [33]. The hybrid system was modelled in HOMER for an off-grid scenario using DC/AC Coupled hybrid configuration.

\subsection{Solar Resource Assessment}

For assessing the option of using solar power, we have considered the solar resources in our simulation. Data on the monthly averages of daily radiation and clearness index are given in Table 1. The solar resource information used for selected case study at 7०26'39.5" N latitude and 3'53'58.2" E longitude was taken from NASA Surface Meteorology. The clearness index is a measure of the fraction of the solar radiation that is transmitted through the atmosphere to the earth's surface. The annual average solar radiation is found to be $4.29 \mathrm{kWh} / \mathrm{m}^{2} / \mathrm{d}$ and the average clearness index is found to be 0.429 .

Table 1. Solar Radiation and Clearance Index

\begin{tabular}{|lcc|}
\hline Month & $\begin{array}{l}\text { Clearance } \\
\text { Index }\end{array}$ & $\begin{array}{c}\text { Daily } \\
\text { Radiation } \\
\left(\mathrm{kWh} / \mathrm{m}^{2} / \mathrm{d}\right)\end{array}$ \\
\hline January & 0.563 & 5.183 \\
February & 0.481 & 4.719 \\
March & 0.488 & 5.043 \\
April & 0.476 & 4.979 \\
May & 0.466 & 4.779 \\
June & 0.428 & 4.300 \\
July & 0.394 & 3.980 \\
August & 0.351 & 3.616 \\
September & 0.434 & 4.477 \\
October & 0.515 & 5.105 \\
November & 0.536 & 4.992 \\
December & 0.563 & 5.057 \\
\hline
\end{tabular}

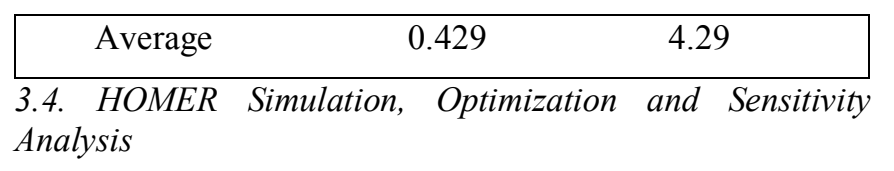

HOMER simulates the operation of a specified system by performing energy balance calculation which is based on the system configuration specified by a designer. The simulation is based on cost of installation, cost of replacement, cost of operation and cost of maintenance.

Once simulation is carried out. HOMER displaces a list of configurations for the hybrid renewable energy system based on the project's levelized cost of energy (COE) and the project's net present value (NPV) of installation and operating costs throughout its lifetime. The resulting hybrid configuration with the least LCOE (Levelized Cost of Energy) or the least total NPC (Net Present Cost) is considered as the optimum hybrid system.

The total net present cost (NPC) of the system is the difference between the present values of all costs over the project lifetime and the present values of all revenue earned over project's lifetime. In order to find the LCOE, the total NPC of the project must be converted to series of equal annual cash flows which is known as total annualized cost calculated by equation (1)

$$
\begin{aligned}
& \text { Total annualized cost }\left(\frac{\$}{\text { year }}\right)=\text { Total NPC * } \\
& \text { CRF }
\end{aligned}
$$

Where:

$$
C R F=\text { Capital Recovery Factor }
$$

Levelized Cost of Energy (LCOE) is the cost per kWh of electrical energy, such that the total NPC of the useful energy generated throughout the whole lifetime of the hybrid project is equal to the total NPC of the project. The calculation of LCOE of the electricity generated by an off-grid hybrid system is done as shown below in the equation (2).

$$
L C O E=\frac{\text { Total Annualized } \operatorname{Cost}(U S \$ / y r)}{\text { Annual load served }\left(\frac{k W h}{y r}\right)}
$$

HOMER software will be used to carry out sensitivity analysis for each configuration considered. The sensitivity variables to be considered in the study are the greenhouse gases such as carbon dioxide, carbon monoxide, unburned hydrocarbon, particulate matter, sulfur dioxide and nitrogen oxides.

\subsection{Load Profile}

The load profile for different types of electrical appliances and machines, such as bulbs, televisions, radios, standing and ceiling fans, air conditioning units, refrigerators, pumping machines etc., used in the hall is graphed in Fig. 1.

The daily and hourly noise inputs help to add randomness to the load data to make it more realistic. Fig. 2 shows how this noise will affect the average load profile. From fig. 2, the designed hybrid system will be for an average of load of 2512 $\mathrm{kWh} / \mathrm{d}$, peak load of $227 \mathrm{~kW}$ at $10 \%$ random variability. 
INTERNATIONAL JOURNAL Of SMART GRID

I. Mofolorunso Opedare et al., Vol.4, No.4, December, 2020

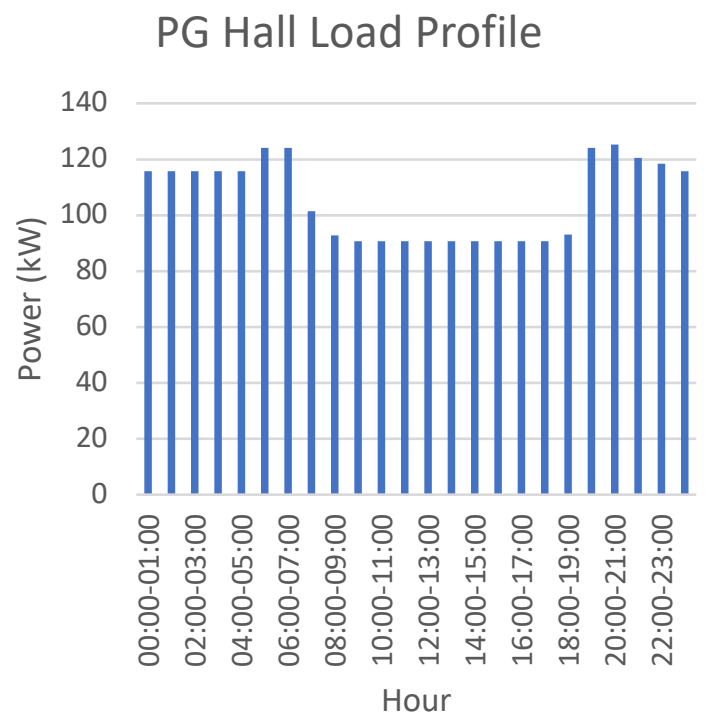

Fig. 1. Load Profile of Abdusalam Abubakar PG Hall

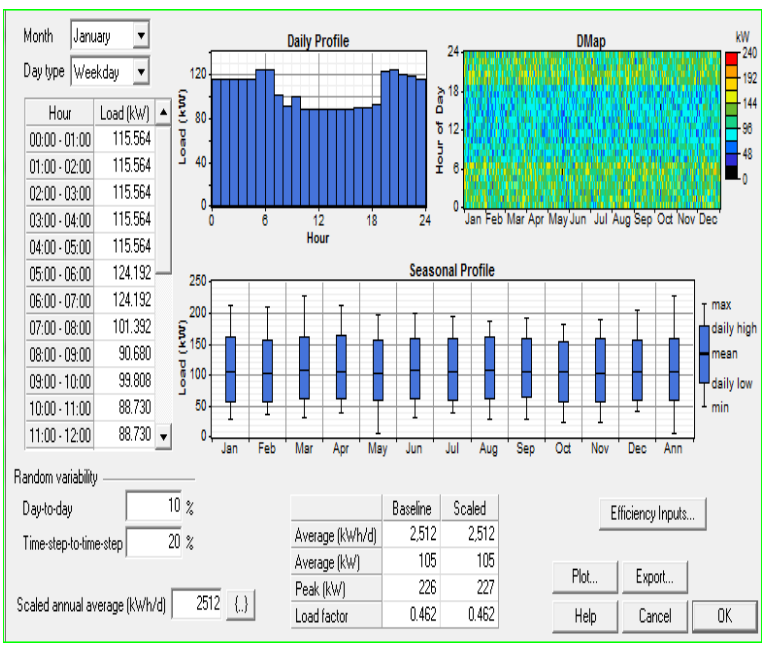

Fig. 2. Load Profile from HOMER Software

\section{Results and Discussion}

\subsection{The Hybrid System Analysis}

The proposed hybrid system to be designed is shown in Fig. 3. It consists of a primary load of $2512 \mathrm{kWh} / \mathrm{d}$ with a peak load of $227 \mathrm{~kW}$ at $10 \%$ random variability, PV system, diesel generator, battery and a converter for alternating current (AC) electrical loads. The HOMER software will determine the best combination for the hybrid system.

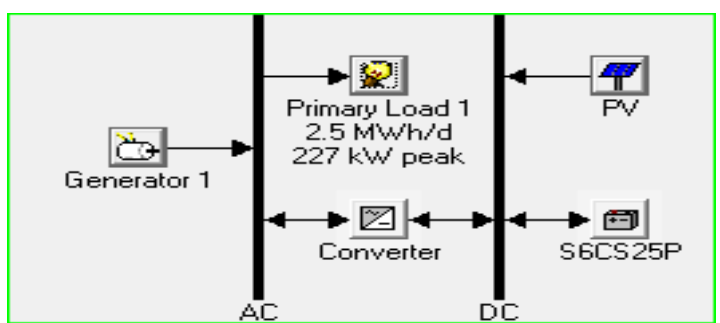

Fig. 3. PV-Diesel hybrid system

\subsection{Optimal Sizing Analysis}

Table 2 summarizes the configuration of the diesel generator, PV and hybrid renewable energy system. The summary of the economic result shows that the annual cost of energy of a $275 \mathrm{kVA}(220 \mathrm{~kW})$ diesel generator system is $\$ 265,479$ with an operating cost of $\$ 263,979 /$ year and net capital cost of $\$ 6,636,975$. However, the optimal size of components for the solar PV system sizes are $1500 \mathrm{~kW} \mathrm{PV}$, $11791 \mathrm{kWh}$ ESS (battery) and $240 \mathrm{~kW}$ converter (inverter) having an annual cost of energy of $\$ 194,911$, operating cost of $\$ 84,447 /$ year and net capital costs of $\$ 4,872,768$. Furthermore, the hybrid renewable energy system had the optimal components size to be $1000 \mathrm{~kW}$ of PV, $5271 \mathrm{kWh}$ ESS, $220 \mathrm{~kW}$ converter and $110 \mathrm{kVA}(88 \mathrm{~kW})$ diesel generator with annual cost of energy of $\$ 159,741$, operating cost of $\$ 104,883 /$ year and net capital costs of $\$ 3,993,533$.

Table 2. Results of optimal configuration

\begin{tabular}{|c|c|c|c|c|}
\hline $\begin{array}{l}\text { Costs and } \\
\text { Parame- } \\
\text { ters }\end{array}$ & Unit & $\begin{array}{l}\text { Diesel gen } \\
\text { case }\end{array}$ & $\begin{array}{l}\text { Solar PV } \\
\text { case }\end{array}$ & $\begin{array}{l}\text { HRES } \\
\text { case }\end{array}$ \\
\hline \multicolumn{5}{|c|}{ Economic results } \\
\hline $\mathrm{COE}$ & $\begin{array}{l}\$ / \mathrm{kW} \\
\mathrm{h}\end{array}$ & 0.290 & 0.215 & 0.175 \\
\hline $\begin{array}{l}\text { Annual } \\
\mathrm{COE}\end{array}$ & $\$ / y r$. & 265,479 & 194,911 & 159,741 \\
\hline $\begin{array}{l}\text { Annual } \\
\text { energy } \\
\text { savings }\end{array}$ & $\$ / y r$. & - & 70,568 & 105,738 \\
\hline $\begin{array}{l}\text { Annual } \\
\text { operating } \\
\text { cost }\end{array}$ & $\$ / y r$. & 263,979 & 84,447 & 104,883 \\
\hline $\begin{array}{l}\text { Net } \\
\text { capital } \\
\text { cost }\end{array}$ & $\$$ & $6,636,975$ & $4,872,768$ & $3,993,533$ \\
\hline \multicolumn{5}{|c|}{ Sizing results } \\
\hline PV & $\mathrm{kW}$ & - & 1,500 & 1,000 \\
\hline ESS & $\mathrm{kWh}$ & - & 11,791 & 5,271 \\
\hline Converter & $\mathrm{kW}$ & - & 240 & 220 \\
\hline $\begin{array}{l}\text { Diesel } \\
\text { Generator }\end{array}$ & $\mathrm{kVA}$ & 275 & - & 110 \\
\hline
\end{tabular}


INTERNATIONAL JOURNAL Of SMART GRID

I. Mofolorunso Opedare et al., Vol.4, No.4, December, 2020

\subsection{Optimized System Analysis}

The optimal hybrid system is the one which can supply electricity needs at the lowest price or in other words, the system which is having the lowest total net present value while supplying the electricity at the required level of availability.

For the off-grid electrification of Abdusalam Abubakar PG Hall, various combinations of hybrid systems have been obtained from the HOMER optimization simulation. The HOMER software arranged the output from the most effective in terms of cost to the least. The optimal system configuration for this case study is $1000 \mathrm{~kW} \mathrm{PV,} \mathrm{110kVA} \mathrm{generator,} 5271$ kWh Surrette S6CS25P battery arranged in parallel strings and a $220 \mathrm{~kW}$ Inverter. The total net present cost (total NPC), and cost of energy (COE) for this optimal hybrid system are $\$ 3,993,533$ and $\$ 0.175 / \mathrm{kWh}$ respectively. The cost breakdown and cash flow projected is shown in Fig. 4 and Fig. 5 respectively.

The energy obtained from the hybrid system is shown in Table 3. The total energy served by the PV array is $1,252,227$ $\mathrm{kWh} / \mathrm{yr}$. which is $81 \%$ of the total energy served. The remaining $19 \%$ is served by the diesel generator which is $288,695 \mathrm{~kW} / \mathrm{yr}$.

The system produces an excess electricity capacity of $456,449 \mathrm{kWh} / \mathrm{yr}$. which cannot be used to serve a load or charge the batteries as shown in Fig. 6.

Table 3. Energy analysis results

\begin{tabular}{|c|c|c|c|c|}
\hline Value & Unit & $\begin{array}{l}\text { Diesel gen } \\
\text { case }\end{array}$ & $\begin{array}{l}\text { Solar PV } \\
\text { case }\end{array}$ & $\begin{array}{l}\text { HRES } \\
\text { case }\end{array}$ \\
\hline \multicolumn{5}{|c|}{ Diesel Generator } \\
\hline $\begin{array}{l}\text { Produc- } \\
\text { tion }\end{array}$ & $\begin{array}{l}\mathrm{kWh} / \\
\mathrm{yr} .\end{array}$ & 923,004 & - & 288,695 \\
\hline $\begin{array}{l}\text { Capacity } \\
\text { factor }\end{array}$ & $\%$ & 47.9 & - & 37.5 \\
\hline \multicolumn{5}{|l|}{ PV } \\
\hline $\begin{array}{l}\text { Produc- } \\
\text { tion }\end{array}$ & $\begin{array}{l}\mathrm{kWh} / \\
\mathrm{yr} .\end{array}$ & - & $1,878,341$ & $1,252,227$ \\
\hline $\begin{array}{l}\text { Capacity } \\
\text { factor }\end{array}$ & $\%$ & - & 14.3 & 14.3 \\
\hline \multicolumn{5}{|l|}{ ESS } \\
\hline $\begin{array}{l}\text { Opera- } \\
\text { tion life }\end{array}$ & yr. & & 12 & 12 \\
\hline $\begin{array}{l}\text { Annual } \\
\text { through- } \\
\text { put }\end{array}$ & $\begin{array}{l}\mathrm{kWh} / \\
\mathrm{yr} .\end{array}$ & & 675,514 & 486,005 \\
\hline \multirow{2}{*}{$\begin{array}{l}\text { Excess } \\
\text { Electri- } \\
\text { city }\end{array}$} & $\begin{array}{l}\mathrm{kWh} / \\
\mathrm{yr} .\end{array}$ & 6,127 & 721,604 & 456,449 \\
\hline & $\%$ & 0.7 & 38.4 & 29.6 \\
\hline
\end{tabular}

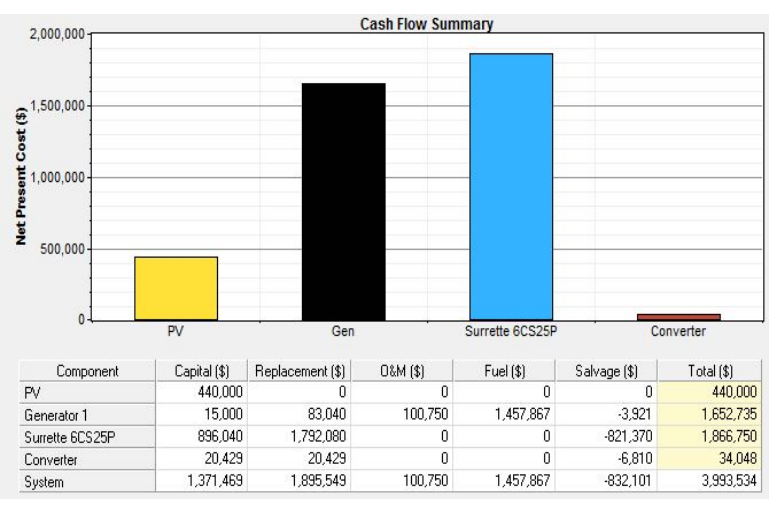

Fig. 4. Cost breakdown of the optimized hybrid system

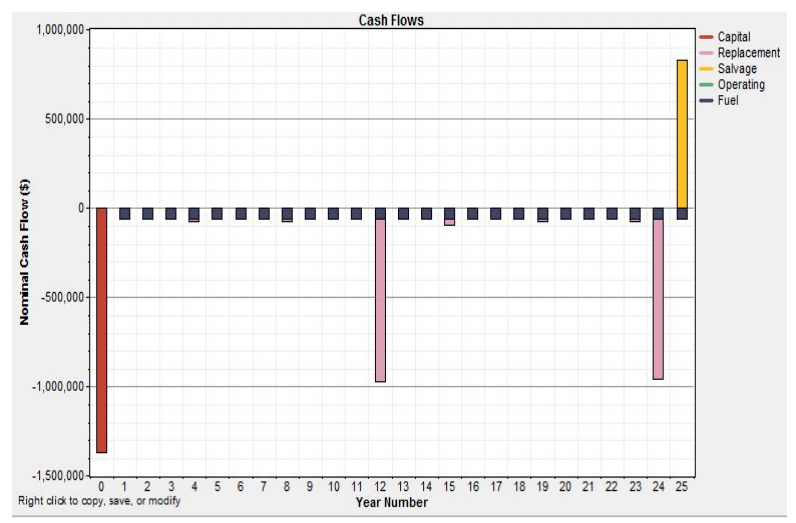

Fig. 5. Cash flow of optimized hybrid system

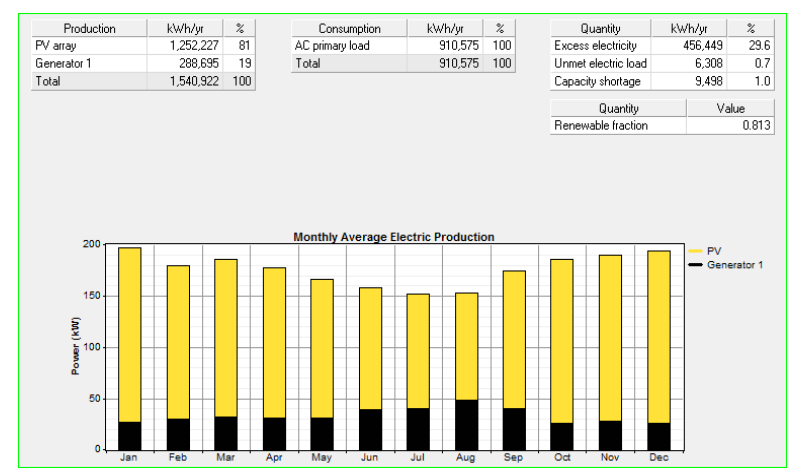

Fig. 6. Energy Obtained from the Optimized Hybrid System

Another system which can be considered for the off-grid electricity supply is a situation in which the solar PV is used as the sole supply of electricity. This proposed designed is shown in Fig. 7.

The optimal system configuration for this case study is 1500kW PV, $11791 \mathrm{kWh}$ Surrette S6CS25P battery arranged in parallel strings and a $240 \mathrm{~kW}$ Converter. The total net present cost (total NPC), and cost of energy (COE) for this optimal hybrid system are $\$ 4,872,768$ and $\$ 0.215 / \mathrm{kWh}$ respectively as shown in Table 2 . The costs breakdown and cash flow for the generator system are shown in Fig. 8 and Fig. 9. 
The system produces an excess electricity capacity of $721,604 \mathrm{kWh} / \mathrm{yr}$. which cannot be used to serve a load or charge the batteries as shown in Fig. 10.

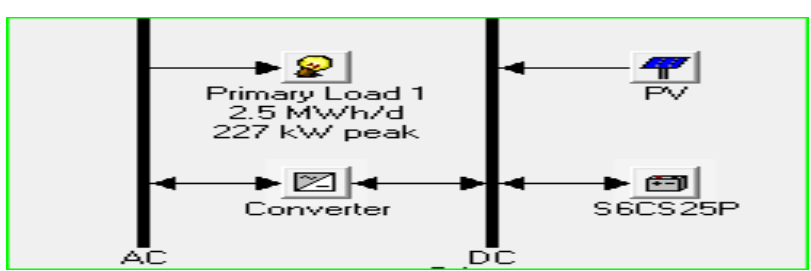

Fig. 7. PV System

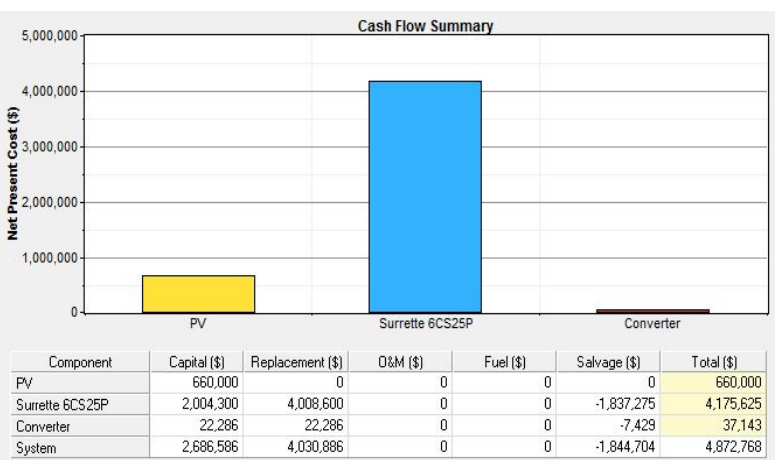

Fig. 8. Cost breakdown of the solar PV system

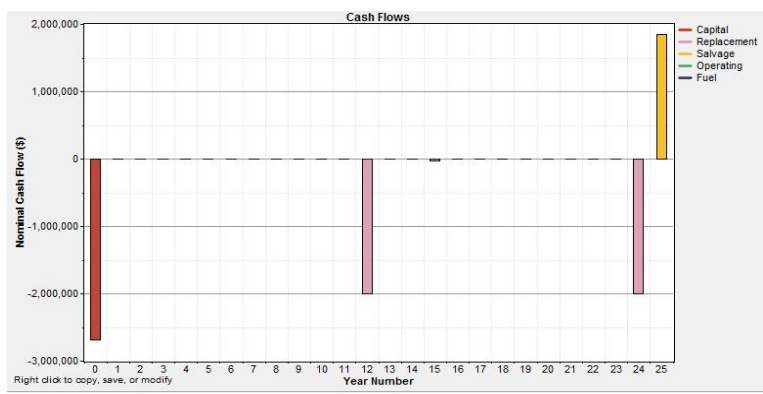

Fig. 9. Cash flow of the solar PV system

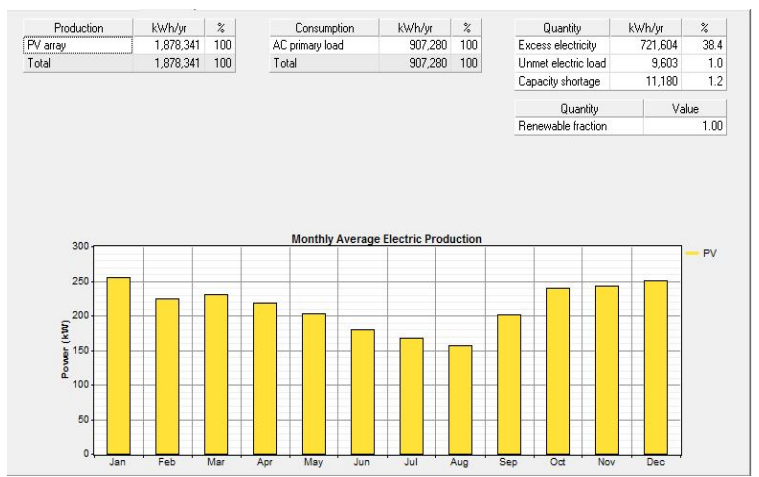

Fig. 10. Energy Obtained from the Optimized PV Standalone System
Another option which can be considered for the off-grid electricity supply is a situation in which the diesel generator is used as the sole supply of electricity. This proposed designed is shown in Fig. 11.

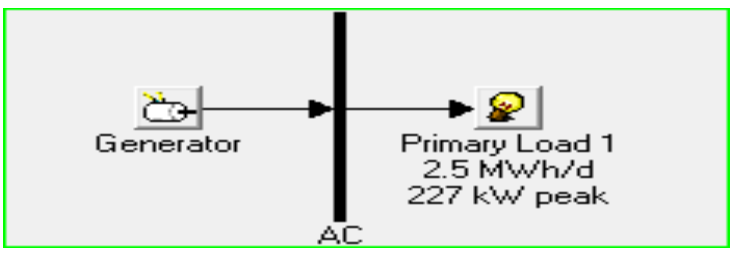

Fig. 11. Generator System

The optimised generator system is a diesel generator of $275 \mathrm{kVA}(220 \mathrm{~kW})$. The total net present cost obtained from the use of the genertor is $\$ 6,636,975$ with a minimun cost of energy of $0.290 \$ / \mathrm{kWh}$, depicted in table 2 . These values are higher when compared to $\$ 3,993,533$ and $\$ 0.175 / \mathrm{kWh}$ obtained for the hybrid system respectively. The costs breakdown and cash flow for the generator system are shown in Fig. 12 and Fig. 13. An excess electricity capacity of 6,127 $\mathrm{kWh} / \mathrm{yr}$. is produced (Fig. 14).

Comparing Fig. 4 and Fig. 12, it can be observed that the fuel cost is higher in the generator system when comparied to the optimised hybrid system. Similarly, in Table 2, operating cost is higher in the generator system than the hybrid system. In constrast, the capital cost and salvage value of the optimised hybrid system are higher when compared to the generator system.

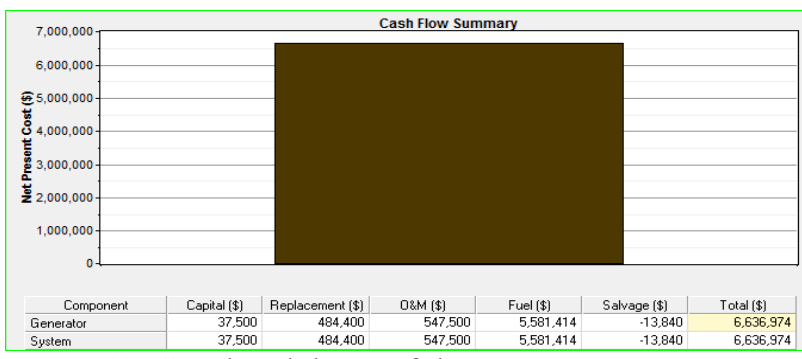

Fig. 12. Cost breakdown of the generator system

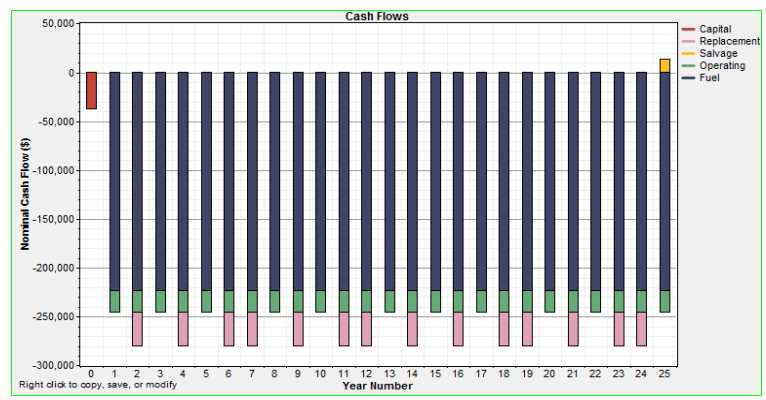

Fig. 13. Cash flow of the generator system 


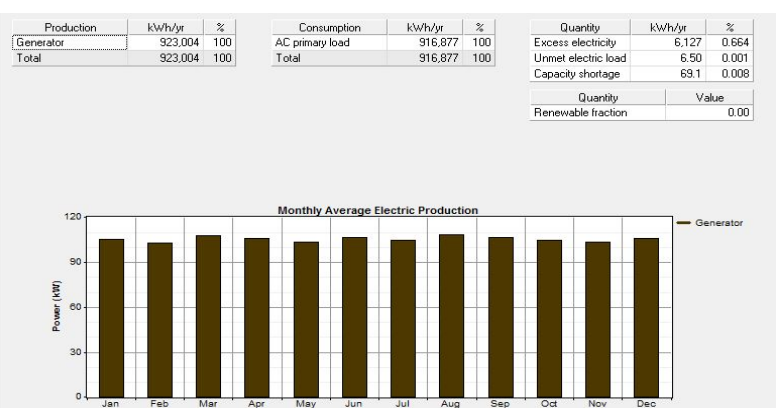

Fig. 14. Energy Obtained from the Optimized Generator System

\subsection{Sensitivity Analysis Based on Green House Gases (GHG)}

To compare the effect of each system on the environment, the derived levels of carbon dioxide $\left(\mathrm{CO}_{2}\right)$ emission are compared in Table 4. The total emission of the diesel generator case is $1,013,635 \mathrm{~kg} / \mathrm{yr}$. of $\mathrm{CO}_{2}$, which reduces to $264,762 \mathrm{~kg} / \mathrm{yr}$. of $\mathrm{CO}_{2}$ for the hybrid system case - a reduction of $74 \%$. From all the pollutant figures reported, the generator system had higher values hence more negative impact on the environment.

Table 4. Emission levels of system

\begin{tabular}{|lllll|}
\hline Pollutant & Unit & $\begin{array}{l}\text { Diesel gen } \\
\text { case }\end{array}$ & $\begin{array}{l}\text { Solar } \\
\text { PV } \\
\text { case }\end{array}$ & $\begin{array}{l}\text { HRES } \\
\text { case }\end{array}$ \\
\hline $\begin{array}{l}\text { Carbon } \\
\text { dioxide }\end{array}$ & $\mathrm{kg} / \mathrm{yr}$. & $1,013,635$ & - & 264,762 \\
$\begin{array}{l}\text { Carbon } \\
\text { monoxide }\end{array}$ & $\mathrm{kg} / \mathrm{yr}$. & 2,502 & - & 654 \\
$\begin{array}{l}\text { Unburned } \\
\text { hydrocarbon }\end{array}$ & $\mathrm{kg} / \mathrm{yr}$. & 277 & - & 72.4 \\
$\begin{array}{l}\text { Particulate } \\
\text { matter }\end{array}$ & $\mathrm{kg} / \mathrm{yr}$. & 189 & - & 49.3 \\
$\begin{array}{l}\text { Sulfur dioxide } \\
\text { Nitrogen }\end{array}$ & $\mathrm{kg} / \mathrm{yr}$. & 2,036 & - & 532 \\
oxides & $\mathrm{kg} / \mathrm{yr}$. & 22,326 & - & 5,831 \\
\hline
\end{tabular}

\section{Conclusion}

This paper aimed to design an off-grid hybrid power system solution from the best combination of hybrid renewable energy technologies for a Hall of Residence. The Hybrid Optimization Model for Electric Renewables (HOMER) software was used for analysis. The components of the system considered were solar photovoltaic (PV), diesel generator, batteries and inverter. The optimised hybrid system obtained was also compared to a system in which a diesel generator serves as the sole source of electricity supply.

Economic analysis using the total net present cost and levelized cost of enegy was employed to determine the optimized hybrid combination. This led to a choice of a hybrid system made up of $1000 \mathrm{~kW} \mathrm{PV,} 110 \mathrm{kVA}$ generator, 11791 kWh Surrette S6CS25P battery arranged in parallel strings and a $220 \mathrm{~kW}$ Inverter due to the lowest total net present cost (total NPC) of $\$ 3,993,553$ and the lowest cost of energy (COE) of $\$ 0.175 / \mathrm{kWh}$. In contrast, the optimized generator system had a total net present cost of $\$ 6,636,975$ and a minimun cost of energy of $0.290 \$ / \mathrm{kWh}$. Analysis also showed that the generator system will have a higher negative impact on the environment. Hence, in terms of economic and environmental considerations, the PV-Diesel hybrid system is preferred to the generator system.

Succinctly put, Hybrid Renewable Energy Systems (HRES) should be employed in the production of energy in general and electricity in particular. This is due to its ability to reduce environmental degradation while ensuring a low total net present cost and a low cost of energy.

For a future work, the RETScreen Clean Energy Management software can be used for analysis [34].

\section{References}

[1] S. C. Bhattacharyya, Energy Economics: Concepts, Issues, Markets and Governance, London: Springer, 2011.

[2] M. Hassan, "Power Generation Methods, Tehniques and Economical Strategy," International Technical Sciences Journal, pp. 43-61, 2014.

[3] EIA, "Nonenewable Energy Explained," 8 August 2018. [Online]. Available: https://www.eia.gov/energyexplained/?page=nonrenewa ble_home. [Accessed August 2018].

[4] TREIA, "Definition of Renewable Energy," 2015. [Online]. Available: http://www.treia.org/renewableenergy-defined.

[5] D. Timmons, J. M. Harris and B. Roach, The Econoics of Renewable Energy, Medford, Massachusetts: Global Development And Environment Institute, 2014.

[6] B. Bhandari, S. R. Poudel, K. T. Lee and S. H. Ahn, "Mathematical Modeling of Hybrid Renewable Energy System: A Review on Small Hydro-Solar-Wind Power Generation," International Journal of Precision Engineering and Manufacturing- Green Technology, vol. 1, pp. 157-173, 2014.

[7] M. Dali, J. Belhadj and X. Roboam, "Hybrid solar-Wind System with Battery Storage Operating in GridConnected and Standalone Mode: Control and Energy Management - Experimental Investigation," Energy, vol. 35, pp. 2587-2595, 2010.

[8] M. Kane, "Small Hybrid Solar Power System," Energy, vol. 28, pp. 1427-1443, 2003.

[9] H. Nabipour-Afrouzi, S. H. Wen Yii, J. Ahmad and M. Tabassum, "Comprehensive Review on Appropriate Sizing and Optimization Technique of Hybrid PV-Wind System," in 2018 IEEE PES Asia-Pacific Power and Energy Engineering Conference (APPEEC), Kota Kinabalu, 2018. 
[10] P. Ganguly, A. Kalam and A. Zayegh, "Design a Control Mechanism for the Power Management of a Standalone Renewable Energy System," in International Conference on Power Electronics, Control and Automation (ICPECA), New Delhi, India, 2019.

[11] NAOC, "Access to Energy Initiatives," 2018. [Online]. Available:

https://www.eni.com/en_NG/sustainability/community/ social-investments/access-to-energy/access-toenergy.shtml. [Accessed 3 October 2018].

[12] InfoGuide Nigeria, "38 power stations in Nigeria, Locations and their Capacities," 2017. [Online]. Available: https://infoguidenigeria.com/power-stationsnigeria/. [Accessed 3 October 2018].

[13] S. Hashimoto, T. Yachi and T. Tani, "New Stand-Alone Hybrid Power System with Wind Turbine Generator and Photovoltaic Modules for a Small-Scale Radio Base Station," IEEJ Transactions on Power and Energy, vol. 11, pp. 1014-1046, 2005.

[14] A. M. Sharaf and M. A. H. El-Sayed, "A Novel Hybrid Integrated Wind-PV Micro Co-Generation Energy Scheme for Village Electricity," Proc. of IEEE International Electric Machines and Drives Conference (IEMDC '09), 2009.

[15] G. C. Bakos, "Feasibility Study of a Hybrid Wind/Hydro Power System for Low-Cost Electricity Production," Applied Energy, vol. 72, pp. 599-608, 2002.

[16] G. Bekele and G. Tadesse, "Feasibility Study of Small Hydro/PV/Wind Hybrid System for Off-Grid Rural Electrification in Ethiopia," Applied Energy, vol. 97, pp. 5-15, 2012.

[17] J. Ram Prabhakar and K. Ragavan, "Power Management Based Current Control Technique for PhotovoltaicBattery Assisted Wind Hydro Hybrid System," International Journal of Emerging Electric Power Systems, vol. 14, pp. 351-362, 2013.

[18] D. Saheb-Koussa, M. Haddadi and M. Belhamel, "Economic and Technical Study of a Hybrid System (wind-photovoltaic-diesel) for Rural Electrification in Algeria," Applied Energy, vol. 86, pp. 1024-1030, 2009.

[19] C. Lao and S. Chungpaibulpatana, "Techno-Economic Analysis of Hybrid Systemfor Rural Electrification in Cambodia," Energy Procedia, pp. 524-529, 2017.

[20] E. A. Al-Ammar, H. U. R. Habib, K. M. Kotb, S. Wang, W. Ko, M. F. Elmorshedy and A. Wasqar, "Residential Community Load Management Based on Optimal Design of Standalone HRES With Model Predictive Control," IEEE Access, vol. 8, pp. 12542-12572, 2020.

[21] S. Rehman, H. U. R. Habib, S. Wang, M. S. Buker, L. M. Alhems and H. Z. Al Garni, "Optimal Design and Model Predictive Control of Standalone HRES: A Real Case Study for Residential Demand Side Management," IEEE Access, vol. 8, pp. 29767-29814, 2020.

[22] C. Ndukwe, T. Iqbal, X. Liang and J. Khan, "Optimal Sizing and Analysis of a Small Hybrid Power System for Umuokpo Amumara in Eastern Nigeria," International Journal of Photoenergy, p. 8 pages, 2019.
[23] L. Aghenta and M. T. Iqbal, "Design and Dynamic Modelling of a Hybrid Power System for a House in Nigeria," International Journal of Photoenergy, p. 13 pages, 2019.

[24] F. Fazelpour, S. Farahi and N. Soltani, "TechnoEconomic Analysis of a Hybrid Power System for a Residential Building in Zabol, Iran," IEEE, 2016.

[25] H. El-houari, A. Allouhi, S. Rehman, M. S. Buker, T. Kousksou, A. Jamil and B. El Amrani, "Feasibility evaluation of a hybrid renewable power generation system for sustainable electricity supply in a Moroccan remote site," Journal of Cleaner Production, vol. 227, pp. 1-12, 2020.

[26] T. Odou, R. Bhandari and R. Adamou, "Hybrid off-grid renewable power system for sustainable rural electrification in Benin," Renewable Energy, vol. 145, pp. 1266-1279, 2020.

[27] M. Nurunnabi and N. K. Roy, "Grid Connected Hybrid Power System Deign Using HOMER," IEEE, 2015.

[28] R. Debnath, N. Soren, S. Bhakta, R. K. Karsh and A. K. Roy, "Feasibility study of an off-grid hybrid renewable energy system," in TENCON 2017 - 2017 IEEE Region 10 Conference, Penang, 2017.

[29] O. M. Babatunde, M. U. Emezirinwune and $H$. Denwigwel, "Hybrid Power System for Off-grid Communities:Techno-Economic and Energy Mix Analysis," IEEE, 2017.

[30] B. P. P. Tchintchui and A. K. Raji, "Techno-economic analysis of a renewable energy solution for an off-grid residence," in International Conference on the Domestic Use of Energy (DUE), Wellington, South Africa, 2019.

[31] G. Lei, H. Song and D. Rodriguez, "Power generation cost minimization of the grid-connected hybrid renewable energy system through optimal sizing using the modified seagull optimization technique," Energy Reports, pp. 1-12, 2020.

[32] B. S. Goud, R. Rekha, M. R. L. Jyostna, S. Sarala, B. L. Rao and C. R. Reddy, "Energy Management and Power Quality Improvement in HRES Grid-Connected System," in 2020 FORTEI-International Conference on Electrical Engineering (FORTEI-ICEE), Bandung, Indonesia, 2020.

[33] L. Olatomiwa, S. Mekhilef, A. S. N. Huda and K. Sanusi, "Techno-economic analysis of hybrid PV-diesel-battery and PV-wind-diesel-battery power systems for mobile BTS: the way forward for rural development," Energy Science and Engineering, pp. 271-285, 2015.

[34] M. I. Abid, M. S. Khalid, M. Kamran, M. A. Rasheed, M. F. Masood and T. Murtaza, "Design and Optimization of the Micro-Hydro Power System for Remote Areas of Pakistan," International Journal of Smart Grid, vol. 4, no. 3, pp. 125-138, 2020. 


\section{APPENDIX I}

Energy Audit

Electrical Appliance(s) and their Power Rating

\begin{tabular}{|l|lllll|}
\hline S/N & \multicolumn{1}{|c}{ Electrical Appliance } & Number in Use & $\begin{array}{c}\text { Power Rating } \\
(\mathrm{W})\end{array}$ & $\begin{array}{c}\text { Total Power } \\
(\mathrm{W})\end{array}$ & $\begin{array}{c}\text { Power } \\
(\mathrm{KW})\end{array}$ \\
\hline 1 & CLF Bulb & 1058 & 13 & 13754 & 13.754 \\
2 & Fluorescent Tube & 352 & 32 & 11264 & 11.264 \\
3 & Incandescent Bulb & 80 & 100 & 8000 & 8 \\
4 & 400W High Pressure Sodium & 24 & 400 & 9600 & 9.6 \\
& Light & & & & 21.91 \\
5 & Ceiling Fan & 313 & 70 & 21910 & 0.13 \\
6 & Standing Fan & 2 & 65 & 130 & 50.52 \\
7 & Laptop & 842 & 60 & 50520 & 4.31 \\
8 & Mobile Phones & 862 & 5 & 4310 & 6.2 \\
9 & Air Conditioning (A/C) Unit & 5 & 1240 & 6200 & 0.72 \\
10 & Television (TV) & 6 & 120 & 720 & 0.15 \\
11 & Decoder & 6 & 25 & 150 & 0.18 \\
12 & Refrigerator & 1 & 180 & 180 & 1.6 \\
13 & Deep Freezer & 8 & 200 & 1600 & 0.1 \\
14 & Desktop PC & 1 & 100 & 600 & 0.6 \\
15 & Printer & 2 & 300 & 2000 & 2 \\
16 & Photocopy Machine & 4 & 500 & 3300 & 3.3 \\
17 & Pumping Machine & 3 & 1100 & 10 & 0.01 \\
18 & Clipper & 1 & 10 & \\
\hline
\end{tabular}


Detailed Daily Consumption for Abdusalam Abubakar Post Graduate Hall

\begin{tabular}{|c|c|c|c|c|c|c|c|c|c|c|c|}
\hline Hour & Bulbs & Fans & $\begin{array}{l}\text { Comput } \\
\text { er }\end{array}$ & $\begin{array}{l}\text { Mob } \\
\text { ile } \\
\text { Pho } \\
\text { ne }\end{array}$ & $\begin{array}{l}\text { Air } \\
\text { Conditioni } \\
\text { ng }\end{array}$ & $\begin{array}{l}\text { TV } \\
\text { Set }\end{array}$ & $\begin{array}{l}\text { Pumpin } \\
\text { g } \\
\text { Machine }\end{array}$ & Refrigerator & $\begin{array}{l}\text { Printing } \\
\text { Machin } \\
\mathrm{e}\end{array}$ & $\begin{array}{l}\text { Clippe } \\
\mathrm{r}\end{array}$ & $\begin{array}{l}\text { Total } \\
\text { Load } \\
\text { (KW) }\end{array}$ \\
\hline $\begin{array}{l}12-1 \\
\mathrm{AM}\end{array}$ & $\begin{array}{l}33.10 \\
4\end{array}$ & 20.37 & 50.4 & $\begin{array}{l}4.22 \\
5\end{array}$ & 4.96 & $\begin{array}{l}0.7 \\
25\end{array}$ & & 1.78 & & & $\begin{array}{l}111.5 t \\
4\end{array}$ \\
\hline $\begin{array}{l}1-2 \\
\mathrm{AM}\end{array}$ & $\begin{array}{l}33.10 \\
4\end{array}$ & 20.37 & 50.4 & $\begin{array}{l}4.22 \\
5\end{array}$ & 4.96 & $\begin{array}{l}0.7 \\
25\end{array}$ & & 1.78 & & & $\begin{array}{l}115.5 t \\
4\end{array}$ \\
\hline $\begin{array}{l}2-3 \\
\text { AM }\end{array}$ & $\begin{array}{l}33.10 \\
4\end{array}$ & 20.37 & 50.4 & $\begin{array}{l}4.22 \\
5\end{array}$ & 4.96 & $\begin{array}{l}0.7 \\
25\end{array}$ & & 1.78 & & & $\begin{array}{l}115.5 \\
4\end{array}$ \\
\hline $\begin{array}{l}3-4 \\
\text { AM }\end{array}$ & $\begin{array}{l}33.10 \\
4\end{array}$ & 20.37 & 50.4 & $\begin{array}{l}4.22 \\
5\end{array}$ & 4.96 & $\begin{array}{l}0.7 \\
25\end{array}$ & & 1.78 & & & $\begin{array}{l}115.5 t \\
4\end{array}$ \\
\hline $\begin{array}{l}4-5 \\
\mathrm{AM}\end{array}$ & $\begin{array}{l}33.10 \\
4\end{array}$ & 20.37 & 50.4 & $\begin{array}{l}4.22 \\
5\end{array}$ & 4.96 & $\begin{array}{l}0.7 \\
25\end{array}$ & & 1.78 & & & $\begin{array}{l}115.5 t \\
4\end{array}$ \\
\hline $\begin{array}{l}5-6 \\
\mathrm{AM}\end{array}$ & $\begin{array}{l}38.43 \\
2\end{array}$ & 20.37 & 50.4 & $\begin{array}{l}4.22 \\
5\end{array}$ & 4.96 & $\begin{array}{l}0.7 \\
25\end{array}$ & 3.3 & 1.78 & & & $\begin{array}{l}124.19 \\
2\end{array}$ \\
\hline $\begin{array}{l}6-7 \\
\mathrm{AM}\end{array}$ & $\begin{array}{l}38.43 \\
2\end{array}$ & 20.37 & 50.4 & $\begin{array}{l}4.22 \\
5\end{array}$ & 4.96 & $\begin{array}{l}0.7 \\
25\end{array}$ & 3.3 & 1.78 & & & $\begin{array}{l}124.19 \\
2\end{array}$ \\
\hline $\begin{array}{l}7-8 \\
\text { AM }\end{array}$ & $\begin{array}{l}15.63 \\
2\end{array}$ & 20.37 & 50.4 & $\begin{array}{l}4.22 \\
5\end{array}$ & 4.96 & $\begin{array}{l}0.7 \\
25\end{array}$ & 3.3 & 1.78 & & & $\begin{array}{l}101.35 \\
2\end{array}$ \\
\hline $\begin{array}{l}8-9 \\
\text { AM }\end{array}$ & 4.16 & 22.04 & 50.62 & 4.31 & 6.2 & $\begin{array}{l}0.8 \\
7\end{array}$ & & 1.78 & 2.6 & 0.1 & 92.68 \\
\hline $\begin{array}{l}9-10 \\
\text { AM }\end{array}$ & 2.288 & 22.04 & 50.62 & 4.31 & 6.2 & $\begin{array}{l}0.8 \\
7\end{array}$ & & 1.78 & 2.6 & 0.1 & 90.808 \\
\hline $\begin{array}{l}10-11 \\
\text { AM }\end{array}$ & 2.21 & 22.04 & 50.62 & 4.31 & 6.2 & $\begin{array}{l}0.8 \\
7\end{array}$ & & 1.78 & 2.6 & 0.1 & 90.73 \\
\hline $\begin{array}{l}11-12 \\
\mathrm{PM}\end{array}$ & 2.21 & 22.04 & 50.62 & 4.31 & 6.2 & $\begin{array}{l}0.8 \\
7\end{array}$ & & 1.78 & 2.6 & 0.1 & 90.73 \\
\hline $\begin{array}{l}12-1 \\
\text { PM }\end{array}$ & 2.132 & 22.04 & 50.62 & 4.31 & 6.2 & $\begin{array}{l}0.8 \\
7\end{array}$ & & 1.78 & 2.6 & 0.1 & 90.652 \\
\hline $\begin{array}{l}1-2 \\
\mathrm{PM}\end{array}$ & 2.132 & 22.04 & 50.62 & 4.31 & 6.2 & $\begin{array}{l}0.8 \\
7\end{array}$ & & 1.78 & 2.6 & 0.1 & 90.652 \\
\hline $\begin{array}{l}2-3 \\
\mathrm{PM}\end{array}$ & 2.132 & 22.04 & 50.62 & 4.31 & 6.2 & $\begin{array}{l}0.8 \\
7\end{array}$ & & 1.78 & 2.6 & 0.1 & 90.65 \\
\hline
\end{tabular}


APPENDIX II Contd.

Detailed Daily Consumption for Abdusalam Abubakar Post Graduate Hall

\begin{tabular}{|c|c|c|c|c|c|c|c|c|c|c|c|}
\hline Hour & Bulbs & Fans & Computer & $\begin{array}{l}\text { Mobil } \\
\mathrm{e} \\
\text { Phon } \\
\mathrm{e}\end{array}$ & $\begin{array}{l}\text { Air } \\
\text { Conditioning }\end{array}$ & $\begin{array}{l}\text { TV } \\
\text { Set }\end{array}$ & $\begin{array}{l}\text { Pumping } \\
\text { Machine }\end{array}$ & Refrigerator & $\begin{array}{l}\text { Printing } \\
\text { Machine }\end{array}$ & Clipper & $\begin{array}{l}\text { Total } \\
\text { Load } \\
\text { (KW) }\end{array}$ \\
\hline $3-4$ PM & 2.132 & 22.04 & 50.62 & 4.31 & 6.2 & 0.87 & & 1.78 & 2.6 & 0.1 & 90.652 \\
\hline $4-5 \mathrm{PM}$ & 2.028 & 21.765 & 50.52 & 4.285 & 4.96 & $\begin{array}{l}0.72 \\
5\end{array}$ & 3.3 & 1.78 & 1.3 & 0.1 & 90.763 \\
\hline $5-6 \mathrm{PM}$ & 2.028 & 21.765 & 50.52 & 4.285 & 4.96 & $\begin{array}{l}0.72 \\
5\end{array}$ & 3.3 & 1.78 & 1.3 & 0.1 & 90.763 \\
\hline $6-7 \mathrm{PM}$ & 4.42 & 21.765 & 50.52 & 4.285 & 4.96 & $\begin{array}{l}0.72 \\
5\end{array}$ & 3.3 & 1.78 & 1.3 & 0.1 & 93.155 \\
\hline 7 - 8 PM & 38.718 & 21.765 & 50.52 & 4.285 & 4.96 & $\begin{array}{l}0.72 \\
5\end{array}$ & & 1.78 & 1.3 & 0.1 & 124.153 \\
\hline 8 - 9 PM & 39.784 & 21.765 & 50.52 & 4.285 & 4.96 & $\begin{array}{l}0.72 \\
5\end{array}$ & & 1.78 & 1.3 & 0.1 & 125.219 \\
\hline 9-10 PM & 37.424 & 20.93 & 50.4 & 4.285 & 4.96 & $\begin{array}{l}0.72 \\
5\end{array}$ & & 1.78 & & & 120.444 \\
\hline 10-11 PM & 36.002 & 20.37 & 50.4 & 4.285 & 4.96 & $\begin{array}{l}0.72 \\
5\end{array}$ & & 1.78 & & & 118.462 \\
\hline 11-12 PM & 33.182 & 20.37 & 50.4 & 4.285 & 4.96 & $\begin{array}{l}0.72 \\
5\end{array}$ & & 1.78 & & & 115.642 \\
\hline
\end{tabular}


APPENDIX III

Cash flow for Hybrid System

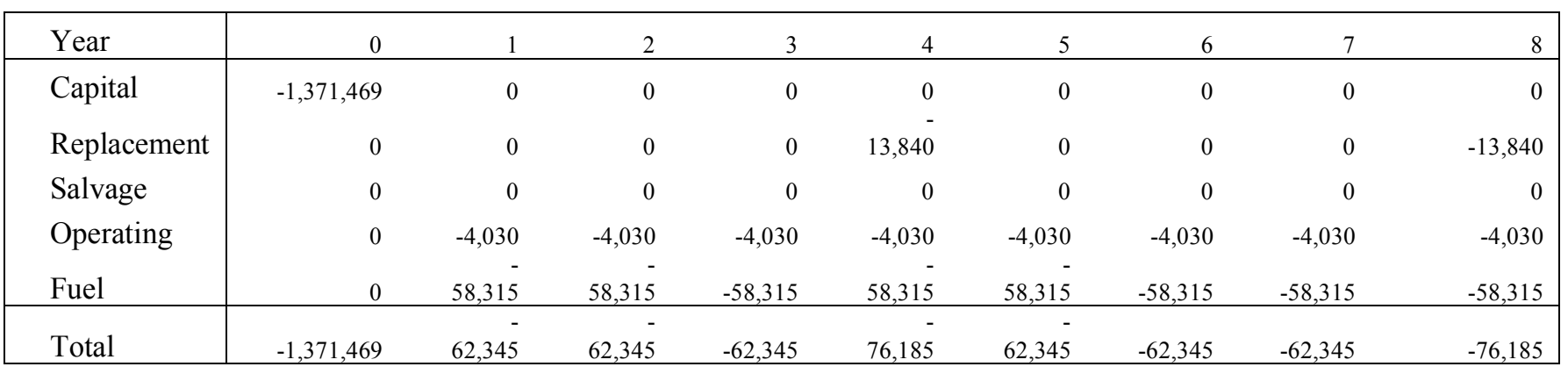

\begin{tabular}{|l|rrrrrrrrr|}
\hline Year & 9 & 10 & 11 & 12 & 13 & 14 & 15 & 16 \\
\hline Capital & 0 & 0 & 0 & 0 & 0 & 0 & 0 & 0 \\
Replacement & 0 & 0 & 0 & 909,880 & 0 & 0 & $-34,269$ & 0 & 0 \\
Salvage & 0 & 0 & 0 & 0 & 0 & 0 & 0 & 0 & 0 \\
Operating & $-4,030$ & $-4,030$ & $-4,030$ & $-4,030$ & $-4,030$ & $-4,030$ & $-4,030$ & $-4,030$ & $-4,030$ \\
Fuel & $-58,315$ & 58,315 & 58,315 & $-58,315$ & 58,315 & 58,315 & $-58,315$ & $-58,315$ & $-58,315$ \\
\hline Total & $-62,345$ & 62,345 & $-62,345$ & $-972,225$ & $-62,345$ & 62,345 & $-96,613$ & $-62,345$ & $-62,345$ \\
\hline
\end{tabular}

\begin{tabular}{|l|rrrrrrrrr|}
\hline Year & 18 & 19 & 20 & 21 & 22 & 23 & 24 & 25 & Total \\
\hline Capital & 0 & 0 & 0 & 0 & 0 & 0 & 0 & 0 & $-1,371,469$ \\
Replacement & 0 & 13,840 & 0 & 0 & 0 & 13,840 & 896,040 & 0 & $-1,895,549$ \\
Salvage & 0 & 0 & 0 & 0 & 0 & 0 & 0 & 832,101 & 832,101 \\
Operating & $-4,030$ & $-4,030$ & $-4,030$ & $-4,030$ & $-4,030$ & $-4,030$ & $-4,030$ & $-4,030$ & $-100,750$ \\
Fuel & $-58,315$ & 58,315 & 58,315 & $-58,315$ & 58,315 & 58,315 & $-58,315$ & $-58,315$ & $-1,457,867$ \\
\hline Total & $-62,345$ & 76,185 & $-62,345$ & $-62,345$ & 62,345 & 76,185 & 958,385 & 769,756 & $-\mathbf{3 , 9 9 3 , 5 3 4}$ \\
\hline
\end{tabular}


INTERNATIONAL JOURNAL Of SMART GRID

I. Mofolorunso Opedare et al., Vol.4, No.4, December, 2020

APPENDIX IV

Cash Flow for Stand-alone PV

\begin{tabular}{|l|rrrrrrrrr|}
\hline Year & 0 & 1 & 2 & 3 & 4 & 5 & 6 & 7 \\
\hline Capital & $-2,686,586$ & 0 & 0 & 0 & 0 & 0 & 0 & 0 \\
Replacement & 0 & 0 & 0 & 0 & 0 & 0 & 0 & 0 \\
Salvage & 0 & 0 & 0 & 0 & 0 & 0 & 0 & 0 \\
Operating & 0 & 0 & 0 & 0 & 0 & 0 & 0 & 0 \\
Fuel & 0 & 0 & 0 & 0 & 0 & 0 & 0 & 0 \\
\hline Total & $-2,686,586$ & 0 & 0 & 0 & 0 & 0 & 0 \\
\hline
\end{tabular}

\begin{tabular}{|l|rrrrrrrr|}
\hline Year & 9 & 10 & 11 & 12 & 13 & 14 & 15 & 16 \\
\hline Capital & 0 & 0 & 0 & 0 & 0 & 0 & 0 & 0 \\
Replacement & 0 & 0 & 0 & $-2,004,300$ & 0 & 0 & $-22,286$ & 0 \\
Salvage & 0 & 0 & 0 & 0 & 0 & 0 & 0 & 0 \\
Operating & 0 & 0 & 0 & 0 & 0 & 0 & 0 & 0 \\
Fuel & 0 & 0 & 0 & 0 & 0 & 0 & 0 & 0 \\
\hline Total & 0 & 0 & 0 & $-2,004,300$ & 0 & 0 & $-22,286$ & 0 \\
\hline
\end{tabular}

\begin{tabular}{|l|rrrrrrrr|r|}
\hline Year & 18 & 19 & 20 & 21 & 22 & 23 & 24 & 25 & Total \\
\hline Capital & 0 & 0 & 0 & 0 & 0 & 0 & 0 & $-2,686,586$ \\
Replacement & 0 & 0 & 0 & 0 & 0 & 0 & $-2,004,300$ & 0 \\
Salvage & 0 & 0 & 0 & 0 & 0 & 0 & 0 & $1,844,704$ \\
Operating & 0 & 0 & 0 & 0 & 0 & 0 & 0 & 0 \\
Fuel & 0 & 0 & 0 & 0 & 0 & 0 & 0 & 0 \\
\hline Total & 0 & 0 & 0 & 0 & 0 & 0 & $-2,004,300$ & $1,844,704$ \\
& & 0 & & & & 0 & 0 \\
\hline
\end{tabular}




\section{APPENDIX V}

\section{Cash flow for Generator}

\begin{tabular}{|l|rrrrrrrrr|}
\hline Year & 0 & 1 & 2 & 3 & 4 & 5 & 6 & 7 \\
\hline Capital & $-37,500$ & 0 & 0 & 0 & 0 & 0 & 0 & 0 \\
Replacement & 0 & 0 & $-34,600$ & 0 & $-34,600$ & 0 & $-34,600$ & $-34,600$ & 0 \\
Salvage & 0 & 0 & 0 & 0 & 0 & 0 & 0 & 0 \\
Operating & 0 & $-21,900$ & $-21,900$ & $-21,900$ & $-21,900$ & $-21,900$ & $-21,900$ & $-21,900$ & $-21,900$ \\
Fuel & 0 & $-223,257$ & $-223,257$ & $-223,257$ & $-223,257$ & 223,257 & $-223,257$ & $-223,257$ & $-223,257$ \\
\hline Total & $-37,500$ & $-245,157$ & $-279,757$ & $-245,157$ & $-279,757$ & 245,157 & $-279,757$ & $-279,757$ \\
\hline
\end{tabular}

\begin{tabular}{|l|rrrrrrrrr|}
\hline Year & 9 & 10 & 11 & 12 & 13 & 14 & 15 & 16 \\
\hline Capital & 0 & 0 & 0 & 0 & 0 & 0 & 0 & 0 \\
Replacement & $-34,600$ & 0 & $-34,600$ & $-34,600$ & 0 & $-34,600$ & 0 & $-34,600$ & 0 \\
Salvage & 0 & 0 & 0 & 0 & 0 & 0 & 0 & 0 \\
Operating & $-21,900$ & $-21,900$ & $-21,900$ & $-21,900$ & $-21,900$ & $-21,900$ & $-21,900$ & $-21,900$ & $-21,900$ \\
Fuel & $-223,257$ & $-223,257$ & $-223,257$ & $-223,257$ & $-223,257$ & 223,257 & $-223,257$ & $-223,257$ & $-223,257$ \\
\hline Total & $-279,757$ & $-245,157$ & $-279,757$ & $-279,757$ & $-245,157$ & 279,757 & $-245,157$ & $-279,757$ & $-245,157$ \\
\hline
\end{tabular}

\begin{tabular}{|l|rrrrrrrrr|r|}
\hline Year & 18 & 19 & 20 & 21 & 22 & 23 & 24 & Total \\
\hline Capital & 0 & 0 & 0 & 0 & 0 & 0 & 0 & 0 & $-37,500$ \\
Replacement & $-34,600$ & $-34,600$ & 0 & $-34,600$ & 0 & $-34,600$ & $-34,600$ & 0 & $-484,400$ \\
Salvage & 0 & 0 & 0 & 0 & 0 & 0 & 0 & 13,840 & 13,840 \\
Operating & $-21,900$ & $-21,900$ & $-21,900$ & $-21,900$ & $-21,900$ & $-21,900$ & $-21,900$ & $-21,900$ & $-547,500$ \\
Fuel & $-223,257$ & $-223,257$ & $-223,257$ & $-223,257$ & $-223,257$ & 223,257 & $-223,257$ & $-223,257$ & $-5,581,414$ \\
\hline Total & $-279,757$ & $-279,757$ & $-245,157$ & $-279,757$ & $-245,157$ & 279,757 & $-279,757$ & $-231,317$ & $\mathbf{- 6 , 6 3 6 , 9 7 4}$ \\
\hline
\end{tabular}

